\title{
Strategies to Cultivate Generation Z Talent in Marketing under the Big Data Era
}

\author{
Fan Mo \\ Guangdong AIB Polytechnic, Guangzhou, China \\ Email: FMo@gdaib.edu.cn
}

How to cite this paper: Mo, F. (2022) Strategies to Cultivate Generation Z Talent in Marketing under the Big Data Era. Open Access Library Journal, 9: e8157. https://doi.org/10.4236/oalib.1108157

Received: November 5, 2021

Accepted: January 3, 2022

Published: January 6, 2022

Copyright () 2022 by author(s) and Open Access Library Inc.

This work is licensed under the Creative Commons Attribution International License (CC BY 4.0).

http://creativecommons.org/licenses/by/4.0/

\begin{abstract}
With the coming of big data era in China, a comprehensive set of skills required of marketing talents include professional marketing knowledge, computer technique, creative and critical thinking, as well as big data thinking. All these skills are crucial for them to succeed in the increasingly competitive global job marketplace. In order to adapt to this era, this paper develops a marketing talent training strategies in our Generation $Z$ students via interdisciplinary education, integration between industry and education, pay more attention on fostering creativity in the class and develop students' personality. This is critical to promote big data thinking with marketing course contents and will be the focus of our future education. Also, author's opinion of this paper aims as a reference for other rapidly developing countries in the marketing education.
\end{abstract}

\section{Subject Areas}

Marketing, Marketing Theory and Applications

\section{Keywords}

Generation Z, Talent Training, Marketing

\section{Introduction}

As a hot spot of science and technology today, big data has a crucial role to play in promoting internet technology, setting off a wave in both academia and business. Closely related to various fields such as cloud computing, artificial intelligence, $5 \mathrm{G}$ technology, big data has gradually become one of our national strategies in accelerating our national economic development. Though big data industry is still in the exploratory stage in its technological development and application, it's obvious that data-driven research on dynamic finance, market place and 
operation management will be the focus of future business and marketing education.

Nowadays, an emerging workforce is the Generation $\mathrm{Z}$ (year of birth between 1995 and 2009) therein majority of them are about to graduate and enter the workforce (Goh \& Lee, 2018) [1]. Generation Z takes up over 20\% of total jobs ${ }^{1}$. Despite the pivotal role of this generation in the workforce, limited studies have been conducted to reveal their general workplace attitudes. Some studies have found the workplace traits of Generation $\mathrm{Z}$ to display confidence, embrace team dynamics, seek future career assurance, and desire workplace delight with preferences for independence to being micro managed (Ozkan \& Solmaz, 2015) [2]. Generation $\mathrm{Z}$ also wants companies to acclimate to social media, offer opportunities to work in more than one country, and provide ongoing feedback over formal annual appraisals (Self et al., 2019) [3]. Most of them have a higher awareness related to personal welfare and emotional experience, and they also pay more attention to getting a sense of achievement from work, pursuing the intrinsic value of work (Li, 2019) [4].

So what should university do to cultivate Generation $\mathrm{Z}$ talents so as to help them better and quick join the marketing workforce after graduation? Since very few studies have been conducted on the combination of big data and Generation $\mathrm{Z}$ talent training in marketing, there is an urgent need to work out and/or provide applicable solutions to some basic related problems, queries, etc. Based on previous research on both Generation $\mathrm{Z}$ and talent management, this paper explores the requirements of marketing talents under the big data era, develops a talent training model to focus on some practical issues in order to better cultivate Generation $\mathrm{Z}$ in marketing that might help promote the reform of marketing teaching and the improvement of the existing talent training mode.

\section{Literature Review}

\subsection{Status Quo of Talent Training}

Lack of technical-orientation thinking. Normally most universities in China have more than 50 students in a business class, lectures still dominate the whole teaching process. Therefore teachers spend lots of time explaining terminology, theory, concept, and marketing model in a 45-mins class. Although examples and cases have been provided to support understanding, there is no practice at all in the class. In the new era, marketing oriented by technology is made easy in that the big data platform can provide more accurate portraits of each consumer. Based on these data, the marketers can more easily implement precise marketing. That's why universities need to think about how to cultivate students majoring in marketing to maintain sensitivity to technology, rather than learning theories and concepts in class.

No practice included in the training programs. Most marketing personnel ${ }^{1}$ IMD. IMD world talent ranking. 2020 [R/OL]. (2021-01-10).

https://www.imd.org/centers/world-competitiveness-center/rankings/world-talent-competitiveness/ 
training programs preferably focused on theories, knowledge, rather than practice, which prevent the graduates from adapting quickly to the real working environments. With the development of Internet economy and big data, speed of knowledge updating is increasingly fast. Simple SWOT analysis and marketing theory cannot keep pace with the time, so integration of big data into some relevant courses should be included in the programs. Although some colleges and universities realized such a demanding situation, a complete and systematic training program for big data marketing talents has not yet been formed. There is an urgent call for reformation.

Lack of individualized training. Generation $\mathrm{Z}$ have specific characteristics, they would like to pursue what they like, and they have a higher awareness of achievement. However, both family and university emphasis more on employment orientation. Generation $\mathrm{Z}$ tend to choose marketing major because their parent or the society want them to do so. They learn things because of different examinations, but not out of their interest. Apart from unified examinations, scheme of work, teaching, notebooks and materials, teaching methods, assessment, and unified evaluation system, the students' brains are flooded with all kinds of established ready-made cultural knowledge. Therefore, no room has been left for their creation and innovation, which is detrimental to the development of students' personality.

\subsection{Requirements of Marketing Knowledge under the Big Data Era}

As a strong practical discipline with high application requirements, marketing developed rapidly over last few decades. With the development of technology and the era of big data, a somewhat mature marketing theory system has been formed, and marketing activities have become more complicated and diversified, ranging from product-orientated to market-orientated, then to customer-orientated today. Modern marketing theory centered on the needs of each target customer has been proposed, together with the new concept of e-marketing, database marketing and precision marketing in the era of big data. The marketers use these new marketing theories to attract customers, to satisfy customers, etc. They can make full use of big data to collect, analyze and organize products, customers, markets, and even competitors information, so as to improve marketing activities, expand marketing channels, target potential consumers, and so on. Therefore, marketing knowledge under the big data era requires various abilities or qualities in terms of personnel or industry.

Big data thinking abilities: Each industry has its own unique way of thinking. In the era of big data, the way of thinking is changing, it requires population rather than samples (full data thinking); efficiency instead of accurate (fault-tolerant thinking); relevant analysis and understanding instead of causality understanding (relevant thinking). These changes require abilities of gaining knowledge and insight into the future from a large amount of data. As it is known to all, with the data collection function of mobile devices, consumers' behaviors can be rec- 
orded at anytime and in everywhere, each of them produces a lot of behavioral data every day. However, the behavioral data of the internet is objectively recorded, providing more possibilities for marketers to explore the authenticity. Under such a basis, marketing class activities should take full advantage of big data, i.e. volume, velocity, variety, value and veracity, using visualization model to help students break the traditional thinking paradigm, so as to maximize the value of marketing's big data thinking ability. Only by cultivating interdisciplinary marketing talents with such data thinking ability can we adapt to the cultivation requirements for the big data talents.

Big data literacy abilities: Data literacy ability is a continuation and expansion of media literacy and information literacy ability, which includes data sensitivity, data collection ability, data analysis and processing ability, using data in decision-making ability and critical thinking ability. Marketing education in this era requires the knowledge of combination of marketing, statistics, computing and electronic information. Take marketing research course as an example, it concentrates more on the combination of offline measurement and online measurement, the combination of substantive problems and online data, the combination of simple random sampling and real-time data.

Big data extension abilities: Data extension ability refers to the ability to analyze and process existing data to solve marketing problems, it includes data acquisition ability, data management ability and data application ability. People who master multiple professional skills of how to use big data to do marketing will be more competitive in decision making. Therefore it is highly recommended that the "big data + marketing" talents training model be practiced in marketing class activities.

\subsection{Steps for Developing a Talent Training Model of Marketing}

Based on the previous literature, a systematic step is developed to construct the talent training strategies related to marketing class under the ear of big data, including three steps, as illustrated in Figure 1.

The first step is to investigate the current status of each universities' Generation $\mathrm{Z}$ student, including their personalities and knowledge background, find out the existing problems of talent training related to marketing. The second step aims to determine the training objectives for developing interdisciplinary and big data thinking talents in marketing. The detailed objective are illustrated in Section 2.2. the third step construct a new talent training model for marketing in China, which includes four parts, i.e. fostering creativity in the class; interdisciplinary education; personality development and integration between industry and education. The characteristics and steps of each part of the talent training strategies are discussed in chapter 3.

\section{Strategies to Cultivate Generation Z in Marketing}

Business schools have recognized the need for revolution for almost 20 years 


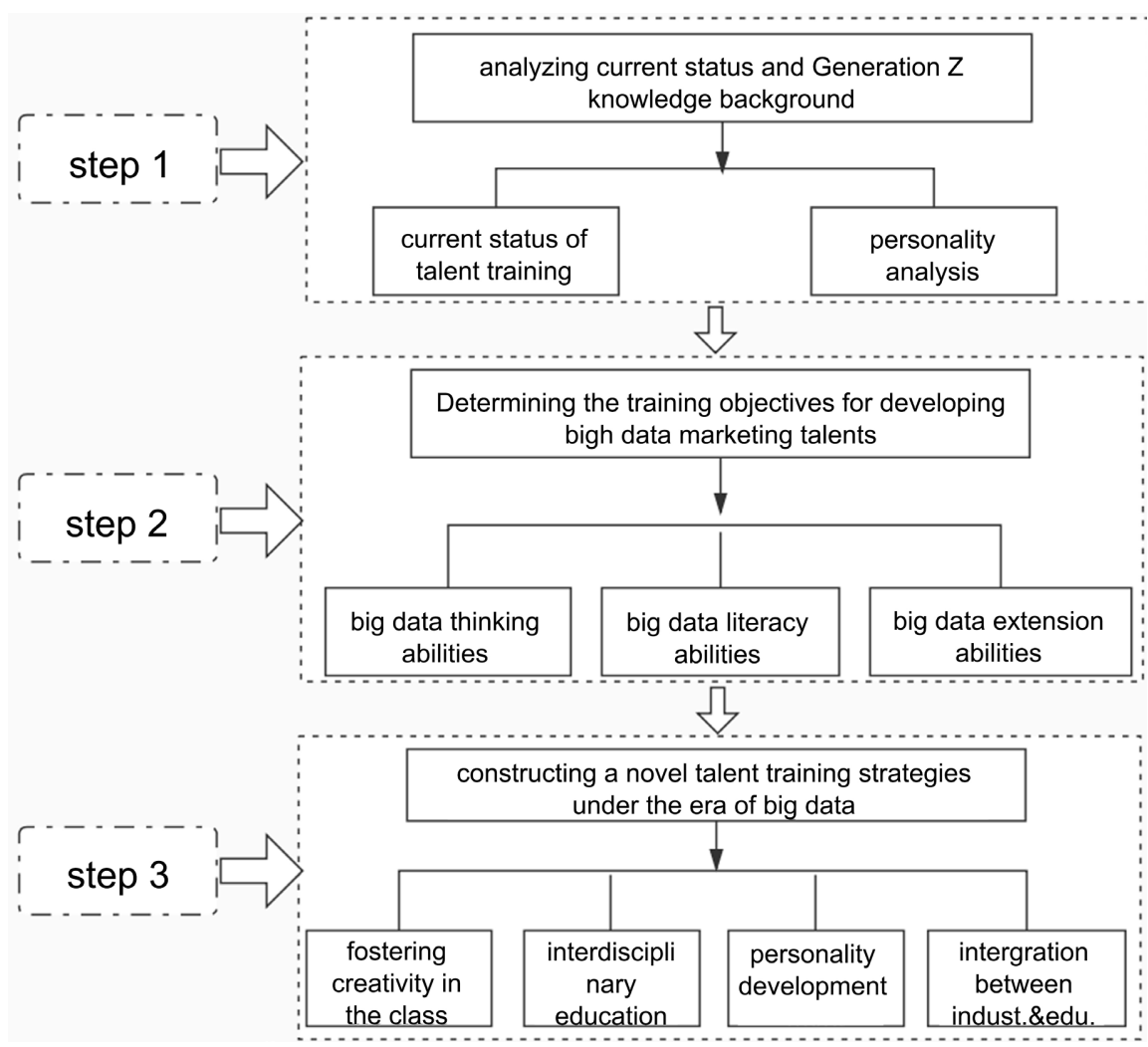

Figure 1. A systematic step for constructing the talent training model.

(Pettigrew \& Hommel, 2013 [5]; McIntyre, Hite \& Richard, 2003 [6]). The marketing education literature has recognized that preparing students for marketing careers require more than content knowledge, the following skills are required as well, e.g. people skills, teamwork, communication, leadership, negotiation, critical thinking, computer technology, public speaking, etc. How should we incorporate various marketing skills and big data thinking into the marketing curriculum is subject to further investigation. Marketing students will be entering a business environment that requires the skills, possessing the ability to adjust rapidly to a new environment. More importantly, they need the skill to create new solutions to business challenges when they are studying in the colleges or universities, then the following four strategies are recommended for colleges and universities in cultivating Generation $\mathrm{Z}$ talent in a marketing class.

\subsection{Fostering Creativity in the Class}

When communicating with the marketplace, marketers need to continually review the buyer-seller exchange process and the emotional impact on consumers that result from the exchange process and the product experience. They should look at environmental changes that potentially affect the communication and exchange process. They also need to respond to new environmental and competitive conditions with innovative and creative solutions. As the society advances, the need for novelty with social value increases. The academic community needs to modify the current marketing curriculum to develop "creative" marketers. 
A good marketing class should provide more than the accepted content of the discipline, which is beneficial to the development of creativity among the students. Through presentations and various classroom activities, a really good marketing class could encourage the students to step out of their comfort zones and challenge their beliefs and understanding of the world, embracing new ideas, concepts and theories. Students will not create unless they are well-motivated by the teachers and are given enough time.

Take marketing management course as example. When asking a marketing manager to differentiate a pizza restaurant to from nearby competitors, what can you expect him to respond the challenge in using of 4Ps creativity? Answering such a question has a lot to do with developing students' creative thinking in the classroom. To start with some general creative exercises, exercises that require the students to offer a solution to problems, they can discuss together, and come up with various answers, which should not necessarily be connected with the logical extension of prior experience. After practicing general creative problem solving, the students are challenged to apply creative problem-solving skills to marketing situations relevant to course (e.g. the concept of 4Ps). There is no definitive set of activities for exercising creativity. One can find expressions of creativity in every walk of life and one can apply creativity in virtually every situation. Creativity exercises must remain as unconstrained as possible, providing maximum freedom of choice. Successful marketers need to be creative thinkers and practice creative thinking to resolve various marketing issues. It is also believed that fostering creativity in the class in this way can enhance the students' interests in learning marketing theory.

Listed below are sample steps used in the class to fostering creativity in marketing course.

Encourage students to think beyond the ordinary. Students can solve the problem in whatever their think from wide range of disciplines or any customer attract strategies. e.g. Cognition psychology; math; economic perspectives; logic problems; interpret stories; create jokes; create stories; etc.

Integrate marketing concepts, definition of $4 P s$ in Marketing. From the perspective of cognition psychology, how can we better packing or design the product; from economic perspective what pricing strategy is most appropriate; In this step, students are required brain-storming to discuss other relative marketing concepts to solve the problems, like SWOT analysis, new product development, AIDA model, integration communication through different channels, and so on.

Develop presentation skills and team-work skills. Present results in teams to answer the questions, i.e. a marketing plan by PPT. It should include creativity and imagination of business slogans, business logos, and creative briefs for an advertising campaign, etc.

\subsection{Interdisciplinary Education}

Following the "new business" talent training goals and models, it is necessary for us to establish a complete interdisciplinary curriculum system, integrating com- 
puter science and big data analysis into marketing courses, and optimizing the integration of data technology, capabilities, and marketing concepts as well. Such courses should include big data marketing, big data customer relationship management, refined operations, etc. During the class, the contents should focus more on solutions to the problems of various marketing application in the " $5 \mathrm{G}+$ mobile internet era" scenarios, allowing Generation $\mathrm{Z}$ to start from actual cases, i.e. from problems to practice, and cultivating Generation $\mathrm{Z}$ to think of complete scenarios, processes and operations to solve the problems.

Calls for an interdisciplinary education are not new, yet higher education institutions remain notoriously stubborn in changing their unidirectional, hierarchical and disciplinary approach to teaching, and interdisciplinary research opportunities are rarely found (Ferreira \& Tilbury, 2012 [7]; Wals, 2010 [8]). Actually, an interdisciplinary education does not require expertise in every discipline, but rather a willingness and ability to interact, communicate and learn from different perspectives. Encouragement of students capacity to think in an interdisciplinary manner is effective. For example, students work in groups in tutorials to develop a group presentation that addressed a key marketing ethical issue, such as deforestation to produce high quality product. Student is encouraged to tackle this issue from perspective of business, consumer behavior, finacial management, environment science, even psychological discipline, and the content of that issue is interdisciplinary.

The curriculum system is the first part of the talent training strategy. The interdisciplinary education to marketing talent at the university level is mainly composed of curriculum setting. Basically, in china, curriculum systems always consist of basic public course, basic discipline course, professional course and professional compulsory course. In this paper, according to the concept of interdisciplinary education as well as the nature of marketing class, curriculum system could be divided into the following six categories in order to achieve previous talent training objectives, as illustrated in Table 1.

Table 1. The curriculum system of talent training for marketing.

\begin{tabular}{ll}
\hline Curriculum category & Curriculum content \\
\hline Basic public course & $\begin{array}{l}\text { University English; University math; Probability theory and mathematical statistics; Computer } \\
\text { technology; Freshman seminar; Ideological and political theory. }\end{array}$ \\
Basic discipline course & $\begin{array}{l}\text { Marketing Management; Marketing Processes and Planning; Human Resource Management; } \\
\text { Organizational Behavior; Marketing Insights and Analytics; Marketing Intelligence. }\end{array}$ \\
Professional compulsory course & $\begin{array}{l}\text { Research Project; Digital Marketing; Integrated Marketing Communications; Marketing } \\
\text { Information Technology Systems. }\end{array}$ \\
& $\begin{array}{l}\text { Innovation and Commercialization; Business Data and Numerical Skills; Digital Business in } \\
\text { Professional elective course }\end{array}$ \\
Practice; Operations Management; Managing Customer Experience; Professional Identity and \\
Practice; Work Experience; Global Business Environment. \\
Course practicum; Internship; Graduation project. \\
General education course & Course-related to humanities; Course-related to social sciences; Course-related to computing \\
& and technology.
\end{tabular}




\subsection{Personality Development}

Generation $\mathrm{Z}$ have strong personality. In the academic context, individual factors appear to have the most significant effects on students' learning outcomes (Hendy \& Biderman, 2019) [9]. Generation Z was born between 1995 and 2009, it is a pivotal and a significant emerging workforce that need to be reckoned with, as they will be the future market leaders. Limited studies have been conducted to reveal their personality and general workplace attitudes. Such studies have found Generation $Z$ to display confidence, embrace team dynamics, seek future career assurance, desire workplace delight, and prefer independence to being micro managed (Ozkan \& Solmaz, 2015) [2]. Therefore, whatever the talent training goal design, courses design, or class activities design during the class, it is necessary to highlight their individual development in the learning process. We need to fully analyze the Generation Z students' knowledge background, understanding their personalities and developing course content and designing case studies with the times to develop academic motivation and interests. Also, it is necessary to select and use of suitable teaching materials, use loose-leaf teaching materials and practical training materials instead of traditional textbook. Integrating professional courses into curriculum ideology and politics, so as to make sure each student has a good ideology and morality. Beside creative thinking courses and major courses, selected course could be set up so as to meet personality development, like traditional art, tea art, vocal music, Chinese Kongfu, cultural appreciation between eastern and western, and so on. Meanwhile, highlight students-centered teaching approaches, adopt different teaching methods to arouse their interests, so as to arouse students to learning initiative, the most popular teaching model such flipped classroom, hybrid online and offline teaching, MOOCs which could be favored by younger generation. Moreover practical projects should be provided after class to promote the students' ability to transform knowledge into action skills. Such projects aid considerably in cultivating the students' big data thinking ability in a real business environment, i.e.: to tap market opportunities from massive data, predict market demand, and analyze consumer behavior to implement their ability to precision marketing.

\subsection{Integration between Industry and Education}

Social division of labor is becoming more diversified and more refined under the era of big data, it is foreseeable that demand for big data marketing talents are dramatically increasing in the following decade. Under this background, it is necessary to develop close relation between education and industry to create the generation Z's big data marketing abilities. Integration between industry and education refers to the cooperation between enterprise and universities, and its cooperation is the basis for creating favorable environment for marketing students.

The paradigm in the integration between industry and education is creation of 
universal information and big data space. Information and data used in communication between people, and in educational and industrial activities play a central role in contemporary society. In business, consumer behaviors influence the marketers to conduct target market activities so as to attract more potential customers. The creation of universal information and big data space could either better help exchange information in education and industry, or facilitate the acceleration of scientific and technological progress. On the other hand, cooperation between enterprises and universities or colleges in the contemporary society, can better solve the problem of unemployment. Moreover the demand for staff would greatly influences the ways and methods of professional training of marketing student.

To sum up, the integration between industry and education is the merge of educational process with industrial activities, which facilitates the process of adaptation of the marketing student to the conditions of future professional field. Therefore, the best way for colleges and universities is to adjust the current talent training mechanism in cultivating professional big data marketing talents. They can combine various factors such as the talent needs of enterprise, joint cultivation of the students' professional competence, combination of theoretical knowledge and superb practical skills, etc. At the university level, the students' theoretical knowledge can be supplemented and improved from the professional marketing courses, while at the enterprise level, the students' practical skills can be further strengthened under the "theory + practice" curriculum system. Only in this way can we realize the integration of industry and education to cultivate big data marketing talents.

\section{Conclusions}

Since the development of big data has pushed various fields into the digital paradigm, the marketing talent training strategies in education needs to be continuously adjusted to improve the students' data thinking ability, data literacy ability and data extension ability. In an ever-changing environment, "big data and creative thinking" is an effective way to train data marketing talents by formulating talent training goals reasonably and timely, plan personalized content scientifically, and innovate training programs continuously. It is suggested that colleges and universities should cultivate big data marketing talents from the integration of industry and education, highlight personalized teaching, strengthen interdisciplinary joint training program, strive to drive the development of marketing with big data as the guidance, so as to improve the training of big data marketing talents. In addition, when cultivating talents for data marketing, it is necessary to make timely adjustments to the talent training mechanism based on actual conditions and market needs.

While this paper provides insights into training Generation $\mathrm{Z}$ talent in marketing, there are limitations for future researchers to follow. Firstly, although we have gained a lot from literature review, our research is exploratory in nature, 
quantitative research could obtain a large amount of data so as to provide more objective fact to build talent training model. Secondly, given that the paper could only come up with a conclusion based on the situation of China, the results may also provide a guidance for other countries, however with cultural different, it should be pointed out that developing talents for market talent is a long-term process, future research is expected to bring more case studies from other couturiers so as to bridge the gap, paving way for future researchers to conduct a more comprehensive research.

\section{Acknowledgements}

This study was supported by the Talent Research Association of Guangdong Province in China. It is a part of a study carried out by Fan Mo as part of her research on the development environment of scientific and technological talents in Guangdong-Hong Kong-Macao Greater Bay Area [Grant Number GDSRCYJH2021-01]. This support is gratefully acknowledged for the partial moneytary funding of this research.

\section{Conflicts of Interest}

The author declares no conflicts of interest.

\section{References}

[1] Goh, E. and Lee, C. (2018) A Workforce to Be Reckoned with: The Emerging Pivotal Generation Z Hospitality Workforce. International Journal of Hospitality Management, 73, 20-28. https://doi.org/10.1016/j.ijhm.2018.01.016

[2] Ozkan, M. and Solmaz, B. (2015) The Changing Face of the Employees: Generation $\mathrm{Z}$ and Their Perceptions of Work (a Study Applied to University Students). Procedia Economics and Finance, 26, 476-483. https://doi.org/10.1016/S2212-5671(15)00876-X

[3] Self, T., Gordon, S. and Jolly, P. (2019) Talent Management: A Delphi Study of Assessing and Developing Gen Z Hospitality Leaders. International Journal of Contemporary Hospitality Management. https://doi.org/10.1108/IJCHM-11-2018-0915

[4] Li, L.L. (2019) “Generation Z”: View of Working as a Group. People’s Tribune, 19, 54-55.

[5] Pettigrew, A. and Hommel, U. (Eds.) (2013) The Institutional Development of Business Schools. Oxford University Press, Oxford. https://doi.org/10.1093/acprof:oso/9780198713364.001.0001

[6] McIntyre, F., Hite, R. and Richard, M (2003) Individual Characteristics and Creativity in the Marketing Classroom: Exploratory Insights. Journal of Marketing Education, 25, 143-149. https://doi.org/10.1177/0273475303254014

[7] Ferreira, J. and Tilbury, D. (2012) Higher Education and Sustainability in Australia: Transforming Experiences, Higher Education's Commitment to Sustainability: From Understanding to Action, Higher Education in the World 4, Palgrave MacMillan. Global University Network for Innovation, Barcelona, Basingstoke, 96-99.

[8] Wals, A. (2010) Between Knowing What Is Right and Knowing That Is It Wrong to Tell Others What Is Right: On Relativism, Uncertainty and Democracy in Environmental and Sustainability Education. Environmental Education Research, 16, 143- 
151. https://doi.org/10.1080/13504620903504099

[9] Hendy, N. and Biderman, M. (2019) Using Bi-Factor Model of Personality to Predict Academic Performance and Dishonesty. The International Journal of Management Education, 17, 294-303. https://doi.org/10.1016/j.ijme.2019.05.003 